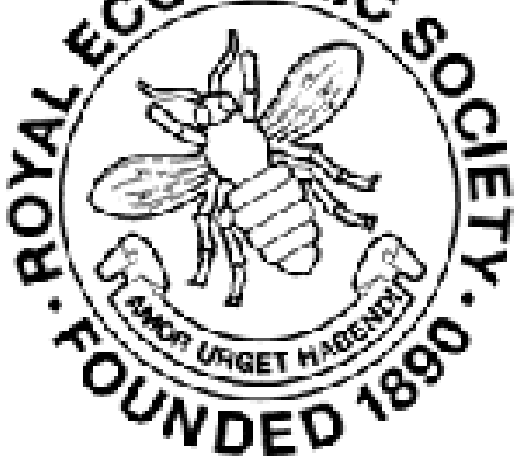

\title{
WILEY
}

\section{Austria and Free Trade}

Author(s): Julius Meinl

Source: The Economic Journal, Vol. 30, No. 118 (Jun., 1920), pp. 254-259

Published by: Wiley on behalf of the Royal Economic Society

Stable URL: http://www.jstor.org/stable/2223026

Accessed: 27-06-2016 08:58 UTC

Your use of the JSTOR archive indicates your acceptance of the Terms \& Conditions of Use, available at

http://about.jstor.org/terms

JSTOR is a not-for-profit service that helps scholars, researchers, and students discover, use, and build upon a wide range of content in a trusted digital archive. We use information technology and tools to increase productivity and facilitate new forms of scholarship. For more information about JSTOR, please contact support@jstor.org.

Royal Economic Society, Wiley are collaborating with JSTOR to digitize, preserve and extend access to The Economic Journal 


\section{Austria and Free Trade}

THe present Succession States (before the war, the AustroHungarian Empire) formed a large area of free trade and above all of free traffic. All these Succession States taken together would, as regards food and the most important necessities of life, be not only self-supporting but, even at the present moment, they would be able to export. As it is they have shut themselves off from each other by restrictions and barriers on the frontiers, which may be called not only artificial, but absurd-nay, mad.

Owing to these barriers it is impossible for the people in the different states to move about freely, to do business or to exchange goods. It is impossible to move goods from the centres of supply to centres of demand. Not only each country, but every district within Austria proper, concentrates the whole of its policy upon keeping all necessary goods within its own frontiers, and if it comes to the exchanging of goods, requires that this be done through officials and through the governments. Governments can never do this business. As the classic on Free Trade, Lord Farrar, says :-

"Every man knows better what he wants to buy and sell than his government can possibly know for him. He will buy and sell to the best advantage if left free to buy and sell as he chooses."

The country which suffers most under these conditions is Austria, and by retaliating she does not make things better. Cobden says with regard to such restrictions and barriers :-

"A foreign tariff is one impediment; over that you have no power. Your own high tariff is another and a separate impediment with an additional and cumulative effect; over this you have power. Remove the impediment over which you have power and do not wait for the removal of the further impediment over which you have no power. You will gain much if you do not gain all."

What is true of tariffs is even more true of the barriers and restrictions which now prevail between the Austrian Succession States. The only possible response Austria can give to these is to open up her frontiers. The free market thus created will prove an enormous attraction for all the surrounding countries. The first consequence will be that the restrictions within the Austrian frontiers would have to fall. It would be impossible for the provincial authorities, with a free market legally established by the central government, to prevent the people, especially the 
peasants, from selling their products in the best market which will be (as in the days before the war) the big towns, which at the present time do not get anything from the country itself because the authorities pay only a fraction of the true market price. Immediately after this the national states would have to follow suit.

If Austria were to remove all passport difficulties, as against the other states, all embargoes on imports and exports, then the populations of the other countries would, in a very short time, force their governments to do the same.

Of course, over a certain time, during the period of transition, help from outside would have to be given to keep the people going, i.e. the industrial population in the big towns, until the next harvest. It would mean the continuance of the support that has been given until now, for another six months. After that time, with free traffic ensured all round, Austria would be able to a great extent to supply herself with the necessary foodstuffs and get the rest in exchange for services rendered to the other States. To carry all this through, it would be necessary to enlighten the people and to explain to them the real economic situation.

There are only two alternatives for Austria-either perfect freedom, free traffic, free exchange of goods, which would gradually re-establish the old economic life in all the Succession States, so that it would not matter where the frontiers are or where the coal lies and so on ; or, alternatively, the maintenance of the present system, which would mean restricting business daily, continuous decrease of production, and, on the other hand, increase of hostility not only between the Succession States but also between town and country, war between the different classes in the country and, in the end, utter chaos and ruin.

Much food will be wanted in the Western countries of Europe, and the crops may just suffice to supply the demand. It will, therefore, be impossible for England and for other countries to extend food supplies to other parts of Europe for any length of time. But, with free exchange of goods ensured, they can easily be self-supporting even at the present time.

Austria does not know the strength of her position; weak as she may appear to be at the present moment in consequence of the restrictions and barriers that are set up on the frontiers, she is the country which, by her geographical situation, by her commercial forces (now paralysed), can most easily upset the whole system, which is bound to ruin not only herself, but all the Succession States of the old Austrian Empire. So she could be an 
object-lesson to the whole world, especially to Germany and Russia, from which countries the original disease started; the original disease was militarism, which translated into economic life means Government control and Bolshevism. Militarism, Government control and Bolshevism believe in the power of brute force to make people do things which they will only do in perfect freedom and if it is worth their while to do them.

Compulsory State control is ruining our production; in fact, our entire economic life. The basis of our economic life in Austria is represented by agriculture, although the many amateurs and know-nothings, who nowadays keep meddling with these matters, will not have it so. Even more than of France, or of Germany, we must say of Austria: "Wealthy farmers mean wealth all round." To-day our agriculture furnishes only a small part of the country's needs, in consequence of compulsory State control, which causes a continual diminution of production and supplies. The greater part of the foodstuffs for the towns must be got from abroad. The most sensible policy would consequently be to increase production as much as possible, and this for two reasons: (1) To lessen the foreign supplies in a gradual manner, till they become superfluous; (2) to secure them at least with certainty for the time during which we cannot feed ourselves by our own production. To-day we are already met by great diffculties in regard to further food-credits, and are told that they were given under the condition that they would be paid back some time. If, however, the most important branch of production in a country is continually oppressed and systematically ruined, the credit of this country will naturally go down. "If you want further credits, you must deserve them. So far you have not shown us any plan for this, and, on the contrary, everything you do makes it impossible for you to pay in future."

To increase production means giving inducements to it. How is this done to-day in Austria, especially in regard to agriculture? By paying the farmer about 5 to 10 per cent. of the sum which his products would fetch in the world's market. The world's market price for wheat to-day is about K.24, the maximum price here is K.2. In England the farmer is paid K.40 for his milk; here we pay him, according to the part of the country he lives in, between K.2 and K.4. This is not veiled, but quite open, confiscation. 
The consequence of such a system, which in reality is equivalent to the methods of the Bolshevists in Russia and Hungary of simply robbing the producer of his products, is that the farmers try everything in their power to prevent the confiscation. They consume as much as possible themselves, feed their stock with the rest or sell it, if possible to illicit dealers. And, if all this is of no avail, they seize arms and give battle to the gendarmes and soldiers who try to take away from them the fruit of their labour. The big landed proprietor, on his part, since he can neither hide his crop nor fight, tills only part of his land, in order to escape requisitioning. For everything he delivers up means a loss to him. If he were to employ farm-hands at the present rate of wages, cultivate extensively and deliver, he would be ruined in no time.

It may be granted that the present situation is a difficult one for the Government. The masses have been fed with the most blatant catchwords, and, not only this, but their worst instincts -envy and hatred-have been roused almost officially. And now the ghosts conjured up will not disappear again. It is impossible to let the prices soar up officially overnight to their proper level (although this will face the officials one day in the form of a catastrophe); a period of transition must therefore be arranged. Reserves must be laid up for the time which will probably elapse till economic life has returned to fairly normal ways. As before, these reserves must be got partly from abroad and partly-as far as possible-at home. In order to get as much as possible at home, the State will have to pay the world's market price to its own farmers as well as to foreigners; it must buy in a free market.

Such a policy will help our own exchange far better than puerile prohibition of exporting banknotes and foreign monies. If the farmers now received the same price as is paid abroad, they could be taxed, and a large part of the outlay would thus return in the form of taxes. In this manner the printing of paper money could be kept within proper limits. While the granting of foreign credits for foodstuffs will cease in a short time, if the present system of compulsory Government control, with its destructive effect upon production, continues, the foreign countries will, from the moment that the production shows an increase, regain confidence in the future of Austria, and even grant further credits.

What kind of a plan has now been devised by our officialdom in order to increase our most important branch of production, viz., our agriculture? So far as can be judged from the news- 
papers, it consists in the following: Maximum prices are to be kept up as before-that is, the farmer will receive only a small fraction of their real worth for the products he must deliver up. We are not informed of the scientific basis of the manner in which these maximum prices have been arrived at. What remains to the farmer over and above the contingent which he must deliver up he may use for himself or give to his stock, etc. But that which he can neither eat himself nor feed his stocks with, he cannot sell at will, but must again deliver it to the State, which will endeavour to give him in return, not money, but articles of necessity! To this end a new institution will be created, with the object of exchanging the agricultural products against the articles needed by the farmers. In other words, new departments with thousands of new officials will arise, to do what our ancestors did 20,000 years ago, before the use of money was known, viz., barter in its most primitive form.

The following tale is now being spread: Last year the contingent system was introduced, yielding to the pressure exercised by the people who stand for free competition trade, but it proved a failure, like the former system of compulsory Government control. This is false. Not the contingent system has been introduced, which has proved its worth in Belgium, but a very injurious law has been set up, which is common to it only in name, and, for the rest, its very opposite, indeed, its entire negation. It was laid down that the farmers need only deliver up a certain contingent (which they could have done easily), the surplus they might use for their own and their families' needs. What they neither sold as contingent nor used themselves, they again had to deliver up to the State at the maximum price.

The contingent system is based upon the idea of enabling the farmer to recoup himself, by selling in a free market, for the loss he suffers from being forced to deliver up a certain quantity to the State. The delivery of the contingent for the State would have become in time a kind of tax which the farmer would have to pay as his share in the feeding of the needy town population. Later on normal conditions would have been reached again, with the difference that the farmer would have had to pay his taxes in foodstuffs, instead of in cash, as formerly. This state of affairs would in its turn have come to an end, for such a system of taxation is, of course, economic folly if it lasts longer than is absolutely necessary. It has been kept up only in Turkey and Asia Minor; all modern States have changed to a monetary basis. It is much more convenient for the State to receive its taxes in the form of 
ready money, and to use this for necessary purchases, than to be its own produce merchant.

The people are being told now that the contingent system failed, and the farmers refused delivery because they would not sell for paper money. This, again, is false. The farmer will sell everything for paper money, provided you pay him the right price. The State has no need to start new fancy firms of its own, which only serve to augment the enormous body of officials, who then proceed to do business in the most uneconomical manner possible, at great cost and without any profit, while this business could be done in a manner far more useful to the community by the people trained to it. Pay the farmer his price, and he will then be able to procure for himself his tools, boots, clothing, etc., with the money in a better and cheaper way than by means of bureaucratic apparatus.

Our economic life must be rebuilt from the bottom. Its base is agriculture. Revive it, and you also revive trade between town and country. With trade and agriculture blossoming, it is easy to restart the handicrafts, which can be done without large quantities of coal or other raw material. As soon as these three most important factors, which fed the vast majority of the population in Austria during normal times, are in full work again, taxes will be paid, our exchange will rise, and with it our credit abroad. And, with our credit re-established, it will be easy to provide for the necessities of our great manufacturing industries. Like Bolshevism, our present system tends to ruin our entire economic life and to spoil all our credit abroad.

Vienna.

\section{Julius MeInL}

\section{Recent Official Publications}

Report by a Court of Inquiry Concerning Transport WorkersWages and Conditions of Employment of Dock Labour. House of Commons Papers, 55. 1920.

The Court reports to the Minister of Labour that with a view to establishing a national minimum standard the minimum for day workers and piece workers shall be $16 s$. per day, on the basis of the National Agreement. This comes to $£ 34 \mathrm{~s}$. a week if, as appears to the Court, the casual worker works eight half-days out of the possible eleven. See review on page 272 .

Forty-eighth Annual Report of the Deputy Master of the Mint (for 1917).

The new silver coin issued in 1917 was just above four million sterling, whereas the amount in 1916 was just above eight million.

No. 118.-VOL. xxx. 